\title{
A Highly Stable Biocatalyst Obtained from Covalent Immobilization of a Non-Commercial Cysteine Phytoprotease
}

\section{Walter David Obregón ${ }^{1}$, José Sebastián Cisneros ${ }^{1}$, Florencia Ceccacci ${ }^{1}$ and Evelina Quiroga ${ }^{2}$}

${ }^{1}$ Research Laboratory Vegetable Proteins (LIPROVE), Faculty of Sciences, National University of La Plata (UNLP), 47 and 115 s / N, La Plata (B1900AVW), Argentina ${ }^{2}$ Membranes and Biomaterials Laboratory, Institute of Applied Physics (INFAP) -CONICET, National University of San Luis (UNSL), Almirante Brown 907, San Luis (D5700HHW), Argentina

\begin{abstract}
In this work, araujiain (enzymatic preparation obtained from the latex of Araujia hortorum fruits) was successfully immobilized on glyoxyl-agarose via multipoint covalent attachment. Thus, good efficiency of immobilization and high operational stability of immobilized enzyme were obtained. The activity of araujiain at alkaline $\mathrm{pH}$ was significantly improved after immobilization. In addition, immobilized araujiain also showed high activity and good stability, without significant loss in its activity, at temperatures between 37 and $60^{\circ} \mathrm{C}$ and in the presence of immiscible organic solvents. Immobilized araujiain also showed good performance in a mixture of $50 \%$ ethyl acetate in buffer, used for peptide synthesis, with better results than when the free enzyme was used as catalyst. These results indicate that immobilized araujiain via multipoint covalent attachment can be highly stabilized and this method might be used for practical applications of araujiain in hydrolytic and synthetic processes.
\end{abstract}

Keywords: Araujiain; Protease; Enzyme technology; Immobilized enzymes; Enzymatic stabilization

\section{Introduction}

Proteases are a family of enzymes that play a prominent role in plant physiology. These enzymes are catalysts of processes such as storage of proteins during seed germination, activation of proenzymes, and degradation of defective proteins $[1,2]$. Due to their good solubility and stability, proteases are widely used in medicine and industry. In particular, alkaline proteases have applications in leather processing [3], laundry detergents [4], production of protein hydrolysates [5] and food processing [6-8]. The recent application of proteases to the production of certain peptides and peptides derivatives has received great attention as a viable alternative to the chemical approach [9-13]. This wide range of applications insures proteases the first place in the world market of enzymes.

In the last decades, proteolytic plant enzymes have received special attention due to their property of being active in a wide range of temperature and $\mathrm{pH}$ values [13-15]. Although the market of commercial proteases includes a high number of proteases with high proteolytic activity and available at a low cost, there is a need to discover new plant sources of more active and more specific proteases.

As the number of practical applications increase, the requirement for bulk amounts of enzyme becomes a limiting factor. Therefore, immobilization is considered to be one possible way to allow the reuse of the enzyme [16-19]. In addition, because immobilization induces rigidification of the enzyme, avoids enzyme aggregation and autolysis, provides considerable stability towards temperature variations and organic solvents and generates a more suitable environment, a high enzymatic stabilization may be achieved [20,21].

Immobilization on solid carriers is perhaps the most used strategy to improve the operational stability of biocatalysts [20,22]. Among the immobilization methods available, multipoint covalent attachment is the most effective in terms of thermal stabilization [23], although gel-entrapped has also been reported to provides thermal stabilization [24,25].

Glyoxyl or glutaraldehyde activated supports have been proven to be quite efficient in increasing tertiary enzyme stability via multipoint covalent attachment, since the formation of additional covalent bonds increases the rigidity of the immobilized enzyme [23]. Immobilization on glyoxyl-carriers occurs at alkaline $\mathrm{pH}$, via the area on the proteins surface richest in lysines. The main advantage of this protocol is the high stability usually achieved.

In this contribution, an immobilized and highly stabilized biocatalyst of araujiain on glyoxyl-agarose via multipoint covalent attachment was accomplished. This enzymatic preparation consisting on three papain-like cysteine peptidases was obtained from the latex of Araujia hortorum fruits (a climbing plant that grows in Brazil, Paraguay, Uruguay and Argentina) [26-28]. Araujiain has been demonstrated to be a successful biocatalyst for the synthesis of amide bonds in aqueous-organic media [9]. N,N-dimethylformamide (with low water content) and mixtures of the Tris- $\mathrm{HCl}$ buffer $(0.1 \mathrm{M}$, $\mathrm{pH}$ 8.5) and hexane, ethyl acetate or propanone in 50:50 ratio were selected to perform the peptide synthesis catalyzed by araujiain. The maximum conversion (35\%) was obtained using ethyl acetate as organic medium [9]. In later work, araujiain was immobilized on diverse supports: i) deposited onto polyamide araujiain demonstrated to be good catalyst for the condensation of coded and non- coded Cbz-amino acids and amines such as amino alcohols and amino acetals in acetonitrile containing $1 \%(\mathrm{v} / \mathrm{v})$ water [13]; ii) the use of titanium dioxide as support for the immobilization of araujiain led to an immobilized biocatalyst with a high protein concentration but with partial deactivation with respect to the native enzyme [29]; iii) entrapped within alginate beads araujiain showed good performance in the peptide synthesis using aqueous-organic media and a secondary structure with a high $\alpha$-helical character was responsible for the

*Corresponding author: Evelina Quiroga, Membranes and Biomaterials Laboratory, Institute of Applied Physics (INFAP) -CONICET, National University of San Luis (UNSL), Almirante Brown 907, San Luis (D5700HHW), Argentina, Tel: 542-652-423-789; E-mail: equiroga@unsl.edu.ar

Received January 26, 2015; Accepted February 24, 2015; Published February 27, 2015

Citation: Obregón WD, Cisneros JS, Ceccacci F Quiroga E (2015) A Highly Stable Biocatalyst Obtained from Covalent Immobilization of a Non-Commercial Cysteine Phytoprotease. J Bioprocess Biotech 5: 211 doi: 10.4172/2155-9821.1000211

Copyright: (C) 2015 Obregón WD, et al. This is an open-access article distributed under the terms of the Creative Commons Attribution License, which permits unrestricted use, distribution, and reproduction in any medium, provided the original author and source are credited. 
highest activity of entrapped araujiain $[25,30]$. Although, it has been proved the remarkable enzymatic activity of araujiain immobilized on diverse supports, there are no studies in the literature reporting the multipoint covalent immobilization of araujiain.

Because of the high biotransformation potential of araujiain, the present study is a natural continuation of our previous work. The main objective was to improve catalytic performance and stability of araujiain through multipoint covalent immobilization on glyoxylagarose for its application to the peptide synthesis in organic medium. The results were compared with those obtained with free araujiain. To our knowledge, this is the first report dealing with the immobilization of araujiain on glyoxyl-agarose and its use in the biocatalysis.

\section{Material and Methods}

\section{Materials}

Synthetic substrates L-pyroglutamyl-L-phenylalanyl-L-leucine p-nitroanilide (PFLNA), L-phenylalanine methyl ester (PheOMe.HCl), $\quad N$-(benzyloxycarbonyl)-L-alanine (Z-Ala) and $N$-(benzyloxycarbonyl)-L-alanine $p$-nitrophenyl ester (ZAla-pNo) were supplied by Bachem (California, USA). Bovine Serum Albumin (BSA) and casein from bovine milk were purchased from Sigma Chemical Co. The rest of the chemicals used in this work were of analytical grade and solvents (hexane and ethyl acetate) were of HPLC grade.

\section{Proteolytic extract preparation}

Araujiain is a proteolytic extract obtained from the latex of fruits of Araujia hortorum Fourn. (Asclepiadaceae) containing papain-like cysteine proteases. The latex obtained by superficial incisions of fruits, gathered in $0.1 \mathrm{M}$ citrate-phosphate buffer ( $\mathrm{pH} 6.5$ ) containing $5 \mathrm{mM}$ EDTA and cysteine as preservatives, was centrifuged at 16,000 $\times g(30$ min at $4^{\circ} \mathrm{C}$ ) in order to discard gums and other insoluble materials. The supernatant was then ultracentrifuged $(100,000 \times g(60 \mathrm{~min}$ at $\left.4^{\circ} \mathrm{C}\right)$ ) and this new supernatant, called araujiain, was fractionated and conserved at $-20^{\circ} \mathrm{C}$ for further studies. Cation exchange chromatography of araujiain reveals the presence of three fractions with proteolytic activity, according to previously described studies by Priolo and Obregón [26,28]. The protein content was estimated according to Bradford's assay using BSA as standard [31]. Whereas that the proteolytic activity of araujiain was determined using casein as substrate in Tris- $\mathrm{HCl}$ buffer $(0.1 \mathrm{M}, \mathrm{pH} 8)$ at $37^{\circ} \mathrm{C}$. Caseinolytic activity was expressed as an arbitrary enzymatic unit (Ucas), according to Priolo et al. [32].

\section{Immobilization of araujiain}

Araujiain was immobilized on glyoxyl-agarose gel via multipoint covalent attachment. Glyoxyl-agarose gel was prepared by etherification of agarose 10 BLC (Hispanagar) with glycidol and further oxidation of the resulting glyceryl-agarose gel with periodates [33]. The immobilization process was carried out according to the protocol used by Guisan [23] with modifications [34]. For this purpose, $10 \mathrm{~g}$ of the activated support were suspended in $25 \mathrm{~mL}$ of $0.1 \mathrm{M}$ sodium bicarbonate buffer ( $\mathrm{pH} 10$ ) containing an appropriate amount of araujiain so as to get a ratio of $35 \mathrm{mg}$ enzyme/g carrier. The obtained suspension was gently stirred at $25^{\circ} \mathrm{C}$ during $20 \mathrm{~h}$. Aliquots of the supernatant and whole suspension were withdrawn at different times and the catalytic activity was measure as described below. The protein content of araujiain solution was determined before and after its contact with the support. The difference in the protein content of the araujiain solution (before and after of immobilization) was considered as the amount of the immobilized enzyme. Finally, derivatives were reduced for $30 \mathrm{~min}$ at $25^{\circ} \mathrm{C}$ adding $0.025 \mathrm{M}$ sodium borohydride $(\mathrm{NaBH})$. The gel was washed with distilled water and $0.1 \mathrm{M}$ Tris-HCl buffer $(\stackrel{4}{\mathrm{pH}} 8.0)$.

\section{Hydrolytic activity assays of immobilized araujiain}

In order to make more accurate the study of the effect of immobilization on the enzyme activity, the hydrolytic activity of immobilized araujiain was measured using a specific chromogenic substrate for papain-like thiol proteases (L-pyroglutamyl-Lphenylalanyl-L-leucine $p$-nitroanilide (PFLNA)). The assay was carried out according to Obregón [15]: $0.1 \mathrm{~mL}$ of biocatalyst $(0.12 \mathrm{~g}$ immobilized araujiain $/ \mathrm{mL}$ ) was added to $1.5 \mathrm{~mL}$ of phosphate buffer (0.1 M, pH 6.5) containing $0.3 \mathrm{M} \mathrm{KCl}, 10 \mathrm{mM}$ EDTA, $3 \mathrm{mM}$ DTT (Dithiothreitol) and $0.18 \mathrm{ml}$ of $4 \mathrm{mM}$ PFLNA. For comparison, an adequate dilution of free araujiain was also tested under same conditions. The liberation of $p$-nitro aniline from PFLNA by hydrolysis of the thiol protease was estimated spectrophotometrically at 410 $\mathrm{nm}$ during $3 \mathrm{~min}$ of reaction at $37^{\circ} \mathrm{C}$ in an orbital shaker at 160 $\mathrm{rpm}$. One unit of protease activity (IU) was defined as the amount of protease which liberated one micromole of $p$-nitro aniline per minute in the assay conditions. These assays were carried out by triplicate, and Standard Deviation (SD) was calculated.

\section{Effect of $\mathrm{pH}$ and temperature}

The effect of $\mathrm{pH}$ on activity of free and immobilized araujiain was studied in the $\mathrm{pH}$ range from 5 to 11 , after $3 \mathrm{~min}$ of reaction at $37^{\circ} \mathrm{C}$, using PFLNA as substrate in $25 \mathrm{mM}$ sodium salts of "Good" buffers (MES, MOPS, TAPS, AMPSO and CAPS) [35].

The effect of temperature was tested by measuring free and immobilized araujian activity at temperatures varying between 27 and $70^{\circ} \mathrm{C}$, after $3 \mathrm{~min}$ of reaction in $0.1 \mathrm{M}$ phosphate buffer $\mathrm{pH} 6.5$ and using PFLNA as substrate. Additionally, thermal stability was evaluated as residual activity (\%) under standard assay conditions, after incubation the enzyme in absence of substrate between 5 and 120 min at $37,45,55,65$ and $75^{\circ} \mathrm{C}$ in $0.1 \mathrm{M}$ phosphate buffer $\mathrm{pH}$ 6.5. The enzyme activity prior to incubation was taken as $100 \%$ at each assayed temperature. All reported results were the average values of three replicates for each experimental condition. Variation coefficients ((Sd Mean $\left.\left.{ }^{-1}\right) 100\right)$ of reported values were less than $2.5 \%$ for activity assays, calculated in each case from triplicate results.

\section{Effect of organic solvents on hydrolytic activity of immobilized araujiain}

The immobilized enzyme ( $2.1 \mathrm{IU} / \mathrm{g}$ carrier) suspended in $0.1 \mathrm{M}$ phosphate buffer $\mathrm{pH} 6.5$ was incubated for $4 \mathrm{~h}$ at $37^{\circ} \mathrm{C}$ under controlled stirring, with an organic phase (hexane or ethyl acetate) at 1:1 ratio. Samples were withdrawn at desired time intervals to test the hydrolytic activity using PFLNA as substrate.

\section{Peptide synthesis catalyzed by immobilized araujiain}

Enzymatic peptide synthesis catalyzed by immobilized araujiain was carried out in an aqueous-organic medium formed by Tris- $\mathrm{HCl}$ buffer $(0.1 \mathrm{M}, \mathrm{pH} 8.5)$ and ethyl acetate at 1:1 ratio, according to conditions established in previous studies $[9,25]$. The condensation reaction was initiated by mixing the aqueous phase containing the immobilized enzyme (2.1 IU/g carrier) and $4 \mathrm{mM}$ Phe-OMe as amino component, with the organic phase containing the carboxylic 
component (Z-Ala or Z-Ala-pNo). The reaction was conducted at $37^{\circ} \mathrm{C}$ in stopper flask under stirring at $160 \mathrm{rpm}$ during $24 \mathrm{~h}$. At time intervals, aliquots were analyzed by HPLC. Simultaneously, blanks with identical composition but without the enzyme and with only the enzyme in the organic system, were analyzed. Gilson HPLC System (Model 712) equipped with a C-18 Luna $(5 \mu \mathrm{m}), 250 \mathrm{~mm} \times$ $4.60 \mathrm{~mm}$ column (Phenomenex) was used. The eluent was a mixture of acetonitrile and water (1:1 ratio), containing $0.1 \%(\mathrm{v} / \mathrm{v})$ trifluoroacetic acid (TFA), at flow rate of $0.8 \mathrm{~mL} / \mathrm{min}\left(254 \mathrm{~nm}\right.$ at $\left.25^{\circ} \mathrm{C}\right)$.

\section{Results and Discussion}

\section{Process of immobilization}

The general conditions for the immobilization of araujiain on glyoxyl-agarose were selected in function of i) the immobilization of other enzymes on glyoxyl-agarose; ii) previous knowledge on the preparation and characterization of the proteolytic extract from $A$. hortorum (Asclepiadaceae) fruit latex, and iii) the non-deactivating conditions for the proteases present in the enzymatic extract: the use of high $\mathrm{pH}$ values does not affect the performance of araujiain $[13,26,28,36]$. Since biocatalysts are designed to perform their activities in aqueous medium and in organic media, the $\mathrm{pH}$ value is important, since it is well established that enzymes "remember" the $\mathrm{pH}$ of the last aqueous solution in which they were dissolved and, after water removal, their ionization state remains unchanged (i.e., the optimum to display its maximum activity) [37].

The proteolytic extract obtained from latex of A. hortorum fruits, named araujiain, was characterized in terms of its protein content and specific activity. The total protein content of araujiain was $5.4 \mathrm{mg}$ protein $/ \mathrm{mL}$ and the specific activity was 12.8 Ucas/ $\mathrm{mg}$ protein (68.4 Ucas/mL araujiain) when casein was used as substrate. Previous studies of Priolo and Obregón [9] reveal the presence of three fractions with proteolytic activity contained in this enzymatic extract $[26,28]$. Such fractions (called araujiain hI, hII and hIII) have synergistic activity and show better performance at different $\mathrm{pH}$ and temperatures in the proteolytic extract that when each working alone and isolated. Although the immobilization of the enzymatic extract obtained in a laboratory containing several enzymes is not an ideal situation, numerous researches have been carried out using this mixture of enzymes [18,38-41]. The properties observed using these crude preparations will be the average of the whole mixture of enzymes able to catalyze the studied reactions.

According to established conditions for the araujiain immobilization, a high percentage of the immobilized enzyme was achieved ( 96\%) (Figure 1). Although $5 \mathrm{~h}$ were enough to achieve the maximum amount of immobilized araujiain, an additional time of $20 \mathrm{~h}$ was used to increase a multipoint attachment. I $\mathrm{t}$ i s well known that long contact periods between enzyme and active support allow the formation of more stable enzyme-support bonds thereby promoting an increase in the stability of the enzyme [42]. After such time, the highest immobilization yield (defined as the ratio between the activity of the immobilized enzyme and the activity of the free enzyme) was obtained ( $\sim 80 \%$; corresponding to $2.1 \mathrm{IU} / \mathrm{g}$ carrier).

Immobilized enzymes are preferred as they can be recycled, resulting in lower production costs. The operational stability of immobilized araujiain was determined for thirty consecutive cycles. Each cycle was defined as the number of enzymatic reactions carried out using PFLNA as substrate, as described in the Material and methods section. Up to twenty six consecutive cycles, no loss of enzymatic activity was observed (Figure 2). Thereafter, a decrease in activity $(<10 \%)$ between 27 th and 30th cycles was observed. Thus, the immobilized enzyme could be reused for several cycles without substantial loss of activity retaining more than $90 \%$ of its initial activity. The decrease $(<10 \%)$ in enzyme activity during repeated use might be due to the frailty associated to agarose structure and the behavior of agarose gels under stirring [43].

As it was demonstrated in previous studies, when araujiain is immobilized onto $\mathrm{TiO}_{2}$ its amidasic activity is drastically reduced with the number of uses (the immobilized catalyst retained $20 \%$ of its initial activity after five cycles) [29]. When araujiain is entrapped into alginate beads, $78 \%$ of the initial enzymatic activity is maintained after twenty cycles [25]. Thus, it was demonstrated better operational stability unlike to previous case or some examples in the literature where some entrapped enzymes in alginate show a minor possibility of reuse [25]. Comparing these results with those obtained when agarose was used as support, it can be concluded that the formation of araujiain-agarose covalent bonds improved the performance of the immobilized enzyme and allowed its use without loss of activity in successive cycles of hydrolytic reactions.

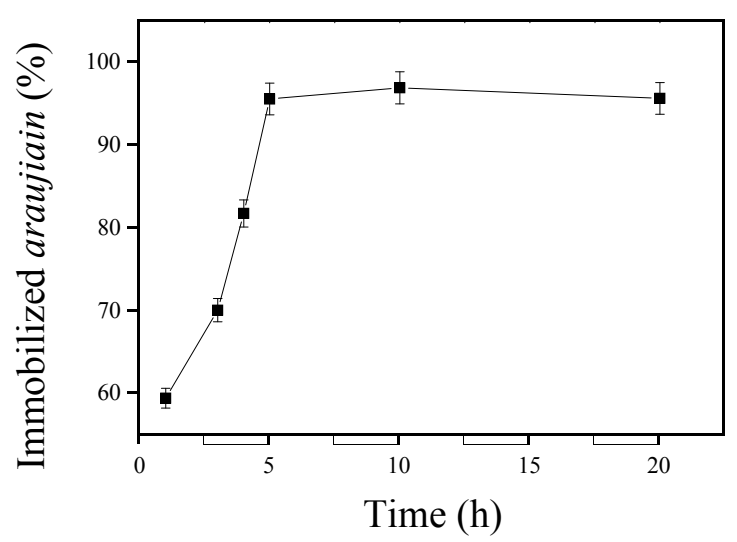

Figure 1: Time course of immobilized araujiain on activated agarose Immobilized araujiain (\%) corresponds to the difference in the protein content of araujiain determined before and after of immobilization.

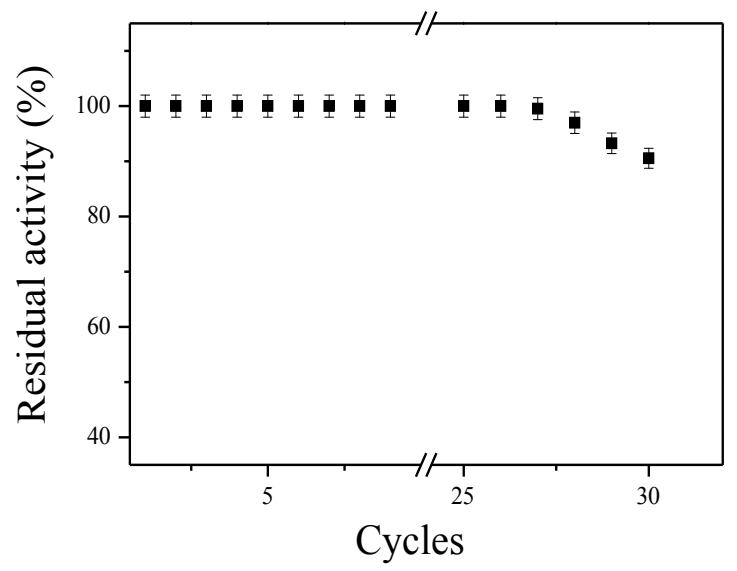

Figure 2: Residual activity (\%) of immobilized araujiain after thirty cycles of the hydrolytic reaction. Each cycle was defined as the number of enzymatic reactions carried out during $3 \mathrm{~min}$ at $37^{\circ} \mathrm{C}$ and using PFLNA as substrate. 


\section{Effect of $\mathrm{pH}$ and temperature}

The effect of $\mathrm{pH}$ on the activity of free and immobilized araujiain was analyzed in the $\mathrm{pH}$ range from 5 to 11 . The curve of free araujiain peaked at $\mathrm{pH} 7$, whereas immobilized araujiain shifted at the optimal $\mathrm{pH}$ of about 2 units toward the high $\mathrm{pH}$ side (from 7 for free araujiain to 9 for immobilized araujiain) (Figure 3). The residual activity of the free enzyme decreased as $\mathrm{pH}$ increased. In contrast, the activity of the enzyme against alkaline $\mathrm{pH}$ was significantly improved upon immobilization, probably due to the stabilization of enzyme molecules resulting from the multipoint attachment on the surface of agarose. At lower $\mathrm{pH}$ ranges, immobilized araujiain showed lower activities than free araujiain (Figure 3). A change in $\mathrm{pH}$ would affect the intramolecular hydrogen bonding leading to a distorted conformation that would reduce the activity of the enzyme. The conformation of the free enzyme would be more favorable in the low $\mathrm{pH}$ range [44].

To analyze the effect of temperature, araujiain immobilized on glyoxyl-agarose was subjected to a range of temperatures from 27 to $70^{\circ} \mathrm{C}$ (Figure 4 ). The free enzyme was simultaneously tested at those temperatures and then compared with the immobilized form. The optimum temperature for the free enzyme was $37^{\circ} \mathrm{C}$. After the immobilization process, a shift in such temperature was observed and immobilized araujiain exhibited highest activity at $45^{\circ} \mathrm{C}$ (Figure $4 \mathrm{a}$ ). As it can be observed, the immobilized enzyme was able to retain a high activity between 30 and $60^{\circ} \mathrm{C}$. Hydrophobic interactions and other secondary interactions of immobilized araujiain might impair the conformational flexibility, needing higher temperatures for the enzyme molecule to reorganize and attain a proper conformation to keep its reactivity [24].

The thermal stability of both free and immobilized araujiain was also analyzed. As it can be observed in figure $4 \mathrm{~b}$, the free enzyme was stable at temperatures ranging between 37 and $55^{\circ} \mathrm{C}$, after $120 \mathrm{~min}$ of incubation. When the temperature was higher, a drastic inactivation was observed. After the same time of incubation, immobilized araujiain was activated, showing a high hydrolytic activity at $55^{\circ} \mathrm{C}$, whereas it was able to retain $70 \%$ and $40 \%$ of initial activity at 65 and $75^{\circ} \mathrm{C}$, respectively (Figure $4 \mathrm{~b}$ ). High activity and good stability, without significant loss in its activity, was observed at the temperatures studied. It is important to highlight that araujiain immobilized on a matrix of glyoxyl-agarose showed similar performance to that observed when araujiain is entrapped in alginate beads [25].

Enzyme thermal inactivation is the consequence of the breaking of the intermolecular forces responsible for maintaining the threedimensional structure, leading to a reduction in its catalytic capacity [45]. The higher stability of immobilized araujiain upon heating may be ascribed to the stabilizing effects of the covalent and secondary interactions between the enzyme and the support [46]. As it is well known, the activation of a support with agents as glycidol generates high concentration of aldehyde groups on the support surface [18,47]. Aldehyde groups in the support and amine groups in the enzyme from lysine residues are a good choice to achieve multipoint attachment and, therefore, to obtain highly thermo-stable enzyme derivatives $[48,49]$. Thermal stability upon immobilization is the result of molecular rigidity and the creation of a protected microenvironment.

\section{Effect of immiscible organic solvents on the hydrolytic activity of immobilized araujiain}

The use of organic solvents as reaction media can thus expand the

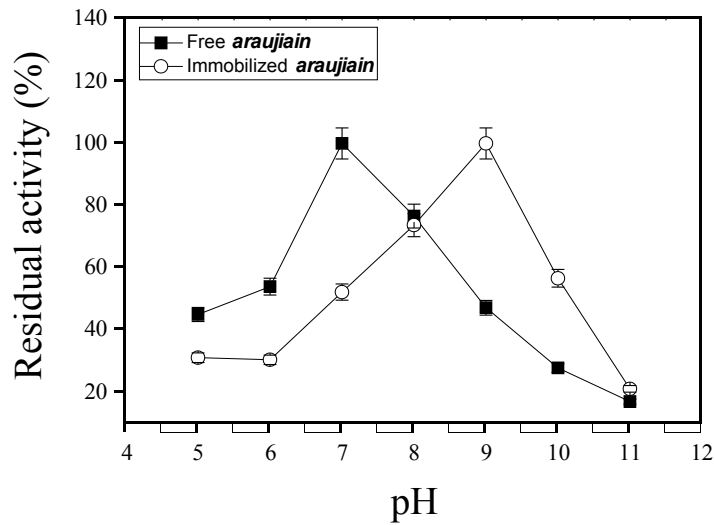

Figure 3: Effect of $\mathrm{pH}$ on the activity of free and immobilized araujiain measured in the $\mathrm{pH}$ range from 5 to 11 , after $3 \mathrm{~min}$ of reaction at $37^{\circ} \mathrm{C}$ and using PFLNA as substrate.

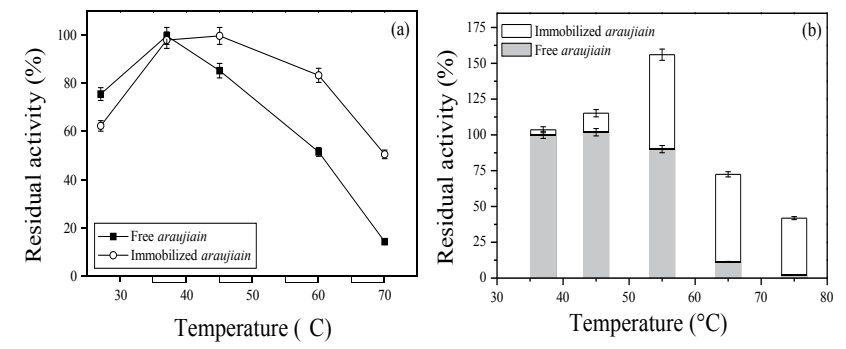

Figure 4: Effect of temperature on the (a) activity (measured at temperatures from 27 to $70^{\circ} \mathrm{C}$, after 3 min of reaction) and (b) stability (after 120 min of incubation at temperatures from 37 to $75^{\circ} \mathrm{C}$ ) of free and immobilized araujiain

repertoire of enzyme-catalyzed transformations [50]. Nevertheless, organic solvents may affect the conformational stability of biocatalysts because these may interact with the hydration layer essential for activity and proper folding, or may alter the protein structure by direct interactions with protein solvation sites [51]. It has been previously demonstrated that free araujiain is not inactivated in aqueousimmiscible organic systems and that it has higher activity in these systems than in buffer $[36,52,53]$. The partition of the organic solvents into the aqueous phase reduces the autolysis degree and produces a considerable activation of araujiain [52]. In this opportunity and taking into account such considerations, hexane and ethyl acetate were selected to study the organic solvent effect on the hydrolytic activity of immobilized araujiain in aqueous-organic mixtures $(0.1$ $\mathrm{M}$ Tris- $\mathrm{HCl}$ buffer $(\mathrm{pH}$ 8.5) and water-immiscible organic solvents at 50:50) as a function of time. This was expressed as a percentage of the initial activity in buffer. High activity and stability were observed in both aqueous-organic media (Figure 5). Nevertheless, the highest activity of immobilized araujiain was observed in 50\% (v/v) hexane. High activity as well as a good stability of the immobilized preparation in organic solvents is one important feature to consider as it allows the use of the enzyme as catalyzer of reactions which are not possible in aqueous phase.

\section{Application of immobilized araujiain to biocatalysis}

Araujiain immobilized on glyoxyl-agarose was used as catalyzer for the synthesis of a precursor of a bitter dipeptide of commercial interest for the food industry (Z-Ala-Phe-OMe). The synthesis was 
performed in a mixture of Tris- $\mathrm{HCl}$ buffer and ethyl acetate $(1: 1$ ratio). Such medium of reaction was selected on the basis of the results previously obtained when the reaction was catalyzed by free araujiain [9]. Although high hydrolytic activity of free araujiain is observed in $50 \%(\mathrm{v} / \mathrm{v})$ hexane, the enzyme is not able to synthesize Z-Ala-Phe- OMe in such medium.

Enzymatic peptide synthesis can be achieved by two different approaches thermodynamically controlled synthesis or kinetically controlled synthesis. In the thermodynamic approach, the acyl donor (an N-terminally protected amino acid) reacts with an acceptor (nucleophile), resulting in the formation of an amide bond. Thermodynamically controlled synthesis is slow and the thermodynamic equilibrium must be shifted towards the synthetic direction by means of product precipitation, water withdrawal, or organic solvent addition [54,55]. In contrast, the kinetic approach involves a C-terminally activated acyl donor that reacts with the nucleophile to give the product in high yields in generally shorter reaction times than the thermodynamic approach [55].

For the kinetically controlled peptide bond formation, Z-Ala- $p$ No was used as the carboxylic component. The highest concentration of the dipeptide Z-Ala-Phe-OMe $(2.23 \mathrm{mM})$ corresponding to the maximum product conversion (Xp: $57.5 \%$ ) was obtained after $1 \mathrm{~h}$ of reaction (Figure 6a). The parameter Xp, which represents the amount of product obtained as a function of the limiting reagent, was defined as the relation between the dipeptide concentration $(\mathrm{mM})$ and the initial concentration $(\mathrm{mM})$ of the limiting reagent (Phe-OMe) [9]. The Xp value here reported was 1.67 -fold higher than that obtained when the free enzyme was used as catalyst under the same reaction conditions [9]. In addition, araujiain immobilized onto agarose showed higher performance than those observed when it was entrapped into alginate beads [25]. After $1 \mathrm{~h}$ of reaction, a decrease in the amount of dipeptide Z-Ala-Phe-OMe was accompanied by an increase in the by-product Z-Ala-Phe, with a maximum conversion of $32 \%$ after $9 \mathrm{~h}$ of reaction (Figure 6a).

When the peptide synthesis was thermodynamically controlled, lower yields were obtained (Xp: $25.25 \%$ ) after $24 \mathrm{~h}$ of reaction (Figure $6 \mathrm{~b})$. Nevertheless, such value of peptide conversion was 1.74 -fold higher than that reported using the free enzyme under the same conditions [9]. After the same reaction time, the results showed here were similar to those obtained when the entrapped araujiain was used as catalyzer [25].

\section{Conclusions}

In this work, araujiain was successfully immobilized on glyoxylagarose by multipoint-attachment: i) good efficiency of immobilization and high operational stability of immobilized enzyme were obtained; ii) the activity of araujiain at alkaline $\mathrm{pH}$ was significantly improved after immobilization; iii) immobilized araujiain also showed high activity and good stability at temperatures between 37 and $60^{\circ} \mathrm{C}$ and in the presence of immiscible organic solvents; iv) immobilized araujiain also showed good performance in a mixture of $50 \%$ ethyl acetate in buffer, used for peptide synthesis, with better results than when the free enzyme was used as catalyst. This behavior can be related to the covalent linkage and secondary interactions (ionic and polar stabilization, hydrogen bonding, etc.) between the enzyme and the support, which enhance the stability of araujiain structure. Thus, considering the low cost of the enzymatic extract used as protease source, the good efficiency of the immobilization and the high operational stability of the immobilized enzyme, this method

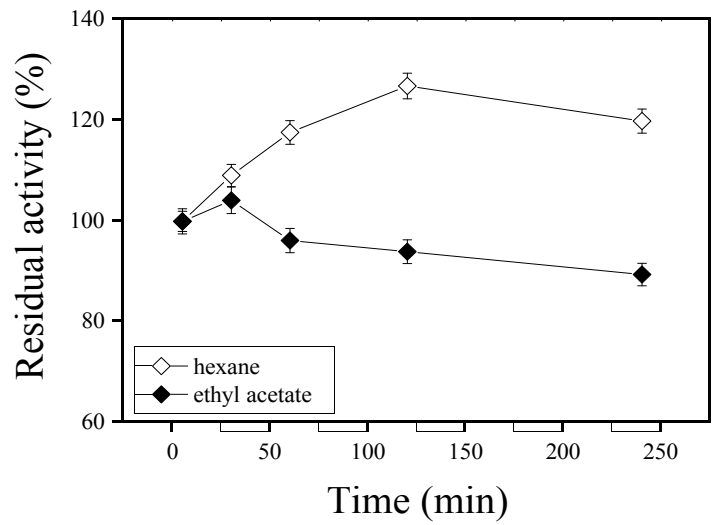

Figure 5: Effect of hexane and ethyl acetate on the hydrolytic activity of immobilized araujiain in aqueous-organic mixtures $(0.1 \mathrm{M}$ Tris- $\mathrm{HCl}$ buffer $(\mathrm{pH}$ 8.5 ) and water-immiscible organic solvents at 50:50) after $4 \mathrm{~h}$ of incubation at $37^{\circ} \mathrm{C}$

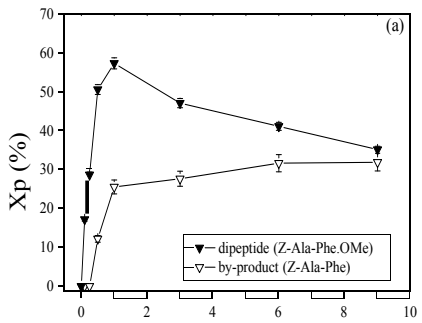

Time (h)

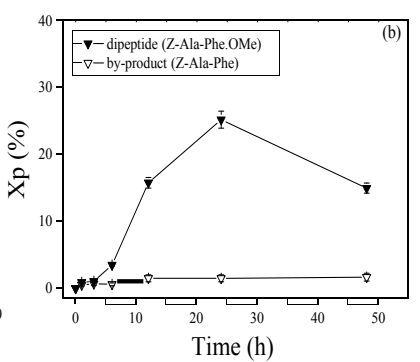

Time (h)
Figure 6: Time-course production of dipeptide Z-Ala-Phe-OMe and by-product (Z-Ala-Phe) in 50\% (v/v) ethyl acetate, using (a) Z-Ala-pNo and (b) Z-Ala as carboxylic components and $\mathrm{Phe}-\mathrm{OMe}$ as amino component. Xp represents the amount of product obtained as a function of the limiting reagent.

might be used for practical applications of araujiain in different applications of biotechnological interest.

\section{Acknowledgments}

The present work was supported by grants from ANPCyT (PICT 02224) CONICET (PIP 0120), PPID X/004 (UNLP) and REDES VII (number 27-52 265). W.D.O. and E.Q. are career members of CONICET; JSC hold a doctoral fellowship from CONICET.

\section{References}

1. van der Hoorn RA (2008) Plant proteases: from phenotypes to molecular mechanisms. Annu Rev Plant Biol 59: 191-223.

2. Parde VD, Aregai T, Abburi MR, Belay K, Saripalli HKRP (2012) Role of the proteolytic enzymes in the living organisms. Int J Int Sci Inn Tech Sec A 4 $32-41$.

3. Dayanandana A, Kanagaraj J, Sounderraj L, Govindaraju R, Rajkumar GS (2003) Application of an alkaline protease in leather processing: an ecofriendly approach. J Clean Prod 11: 533-536.

4. Barberis S, Quiroga E, Barcia C, Liggieri C (2013) Effect of laundry detergent formulation on the performance of alkaline phytoproteases. Electron $\mathrm{J}$ Biotechnol 16: 1-8.

5. Rocha C, Goncalves MP, Teixeira JA (2011) Immobilization of trypsin on spent grains for whey protein hydrolysis. Process Biochem 46: 505-511.

6. González-Rábade N, Badillo-Corona JA, Aranda-Barradas JS, Oliver-Salvado Mdel C (2011) Production of plant proteases in vivo and in vitro--a review. Biotechnol Adv 29: 983-996. 
Citation: Obregón WD, Cisneros JS, Ceccacci F Quiroga E (2015) A Highly Stable Biocatalyst Obtained from Covalent Immobilization of a NonCommercial Cysteine Phytoprotease. J Bioprocess Biotech 5: 211 doi: 10.4172/2155-9821.1000211

Page 6 of 7

7. Feijoo-Siota L, Villa TG (2011) Native and biotechnologically engineered plant proteases with industrial application. Food Bioprocess Technol 4: 1066-1088.

8. Bajaj BK, Jamwal G (2013) Thermostable alkaline protease production from Bacillus pumilus D-6 by using agro-residues as substrates. Adv Enzyme Res 1: $30-36$

9. Quiroga E, Priolo N, Obregón D, Marchese J, Barberis S (2008) Peptide synthesis in aqueous-organic media catalyzed by proteases from latex of Araujia hortorum (Asclepiadaceae) fruits. Biochem Eng J 39: 115-120.

10. Hernáiz MJ, Alcántara AR, García JI, Sinisterra JV (2010) Applied biotransformations in green solvents. Chemistry 16: 9422-9437.

11. Viswanathan K, Omorebokhae R, Li G, Gross RA (2010) Protease-catalyzed oligomerization of hydrophobic amino acid ethyl esters in homogeneous reaction media using I-phenylalanine as a model system. Biomacromolecules 11: $2152-2160$.

12. Xu J, Jiang M, Sun H, He B (2010) An organic solvent-stable protease from organic solvent-tolerant Bacillus cereus WQ9-2: purification, biochemical properties, and potential application in peptide synthesis. Bioresour Technol 101: 7991-7994.

13. Morcelle SR, Cánepa AS, Padró JM, Llerena-Suster CR, Clapés P (2013) Syntheses of dipeptide alcohols and dipeptide aldehyde precursors catalyzed by plant cysteine peptidases. J Mol Catal B: Enzym 89: 130-136.

14. Llorente BE, Obregón WD, Avilés FX, Caffini NO, Vairo-Cavalli S (2014) Use of artichoke (Cynara scolymus) flower extract as a substitute for bovine rennet in the manufacture of Gouda-type cheese: characterization of aspartic proteases. Food Chem 159: 55-63.

15. Obregón WD, Lufrano D, Liggieri CS, Trejo SA, Vairo-Cavalli SE, et al. (2011) Biochemical characterization, cDNA cloning, and molecular modeling of araujiain all, a papain-like cysteine protease from Araujia angustifolia latex. Planta 234: 293-304.

16. Hanefeld U, Gardossi L, Magner E (2009) Understanding enzyme immobilisation. Chem Soc Rev 38: 453-468.

17. Torres-Salas $P$, del Monte-Martinez A, Cutiño-Avila B, Rodriguez-Colinas B Alcalde M, et al. (2011) Immobilized biocatalysts: novel approaches and tools for binding enzymes to supports. Adv Mater 23: 5275-5282.

18. Rodrigues RC, Ortiz C, Berenguer-Murcia Á, Torres R, Fernández-Lafuente $R$ (2013) Modifying enzyme activity and selectivity by immobilization. Chem Soc Rev 42: 6290-6307.

19. Sheldon RA, van Pelt S (2013) Enzyme immobilisation in biocatalysis: why, what and how. Chem Soc Rev 42: 6223-6235.

20. Garcia-Galan C, Berenguer-Murcia A, Fernandez-Lafuente R, Rodrigues RC (2011) Potential of different enzyme immobilization strategies to improve enzyme performance. Adv Synth Catal 353: 2885-2904.

21. Aissaoui N, Landoulsi J, Bergaoui L, Boujday S, Lambert JF (2013) Catalytic activity and thermostability of enzymes immobilized on silanized surface: influence of the crosslinking agent. Enzyme Microb Technol 52: 336-343.

22. Mateo C, Palomo JM, Fernandez-Lafuente G, Guisan JM, FernandezLafuente R (2007) Improvement of enzyme activity, stability and selectivity via immobilization techniques. Enzyme Microb Technol 40: 1451-1463.

23. Guisán JM, Bastida A, Blanco RM, Fernández-Lafuente R, Garcia-Junceda E (1997) Immobilization of enzymes on glyoxyl agarose: Strategies for enzyme stabilization by multipoint attachment. Immobilization of enzymes and cells. Bickerstaff GF (editor) Humana Press, Totowa NJ, USA, pp 277-287.

24. Munjal N, Sawhney SK (2002) Stability and properties of mushroom tyrosinase entrapped in alginate, polyacrylamide and gelatin gels. Enzyme Microb Technol 30: 613-619.

25. Quiroga E, Illanes CO, Ochoa NA, Barberis S (2011) Performance improvement of araujiain, a cystein phytoprotease, by immobilization within calcium alginate bead. Process Biochem 46: 1029-1034.

26. Priolo N, Morcelle del Valle S, Arribére MC, López L, Caffini N (2000) Isolation and characterization of a cysteine protease from the latex of Araujia hortorum fruits. J Protein Chem 19: 39-49.

27. Priolo N, Arribére CM, Caffini N, Barberis S, Vázquez RN, et al. (2001) Isolation and purification of cysteine peptidases from the latex of Araujia hortorum fruits. Study of their esterase activities using partial least-squares (PLS) modeling. J Mol Catal B: Enzym 15: 177-189.
28. Obregón WD, Arribére MC, del Valle SM, Liggieri C Caffini N, et al. (2001) Two new cysteine endopeptidases obtained from the latex of Araujia hortorum fruits. J Protein Chem 20: 317-325.

29. Llerena-Suster CR, Foresti ML, Briand LE, Morcelle SR (2009) Selective adsorption of plant cysteine peptidases onto $\mathrm{TiO}_{2}$. Colloids Surf B Biointerfaces 72: $16-24$

30. Illanes CO, Quiroga E, Camí GE, Ochoa NA (2013) Evidence of structura changes of an enzymatic extract entrapped into alginate beads. Biochem Eng J 70: 23-28.

31. Bradford MM (1976) A rapid and sensitive method for the quantitation of microgram quantities of protein utilizing the principle of protein-dye binding Anal Biochem 72: 248-254.

32. Priolo NS, López LMI, Arribére MC, Natalucci CL, Caffini NO (1991) New purified plant proteinases for the food industry. Acta Alimentaria 20: 189-196.

33. Blanco RM, Calvete JJ, Guisán JM (1988) Immobilization-stabilization of enzymes; variables that control the intensity of the trypsin (amine)-agarose (aldehyde) multipoint attachment. Enzyme Microb Technol 11: 353-359.

34. Obregón WD, Ghiano N, Tellechea M, Cisneros JS, Lazza CM, et al. (2012) Detection and characterization of a new metallocarboxypeptidase inhibitor from Solanum tuberosum cv. Desirèe using proteomic techniques. Food Chem 133 1163-1168.

35. Good NE, Izawa S (1972) Hydrogen ion buffers. Methods Enzymol 24: 53-68.

36. Barberis S, Quiroga E, Morcelle S, Priolo N, Luco JM (2006) Study of phytoproteases stability in aqueous-organic biphasic systems using linear free energy relationships. J Mol Catal B: Enzym 38: 95-103.

37. Polizzi KM, Bommarius AS, Broering JM, Chaparro-Riggers JF (2007) Stability of biocatalysts. Curr Opin Chem Biol 11: 220-225.

38. Palomo JM, Segura RL, Mateo C, Terreni M, Guisan JM, et al. (2005) Synthesis of enantiomerically pure glycidol via a fully enantioselective lipase-catalyzed resolution. Tetrahedron: Asymmetry 16: 869-874.

39. Palomo JM, Ortiz C, Fernandez-Lorente G, Fuentes M, Guisan JM, et al. (2005) Lipase-lipase interactions as a new tool to immobilize and modulate the lipase properties. Enzyme Microb Technol 36: 447-454.

40. Masuda M, Sakurai A, Sakakibara M (2001) Effect of enzyme impurities on phenol removal by the method of polymerization and precipitation catalyzed by Coprinus cinereus peroxidase. Appl Microbiol Biotechnol 57: 494-499.

41. Lotti M, Grandori R, Fusetti F, Longhi S, Brocca S, et al. (1993) Cloning and analysis of Candida cylindracea lipase sequences. Gene 124: 45-55.

42. Bolivar JM, Wilson L, Ferrarotti SA, Guisán JM, Fernández-Lafuente R, et al. (2006) Improvement of the stability of alcohol dehydrogenase by covalent immobilization on glyoxyl-agarose. J Biotechnol 125: 85-94.

43. Mateo C, Palomo JM, Fuentes M, Betancor L, Grazu V, et al. (2006) Glyoxy agarose: A fully inert and hydrophilic support for immobilization and high stabilization of proteins. Enzyme Microb Technol 39: 274-280.

44. Reshmi R, Sanjay G, Sugunan S (2007) Immobilization of a-amylase on zirconia: A heterogeneous biocatalyst for starch hydrolysis. Catal Commun 8 : 393-399.

45. Gupta MN (1991) Thermostabilization of proteins. Biotechnol Appl Biochem 14: 1-11.

46. Le-Tien C, Millette M, Lacroix M, Mateescu MA (2004) Modified alginate matrices for the immobilization of bioactive agents. Biotechnol Appl Biochem 39: $189-198$

47. Adriano WS, Mendonça DB, Rodrigues DS, Mammarella EJ, Giordano $\mathrm{RL}$ (2008) Improving the properties of chitosan as support for the covalent multipoint immobilization of chymotrypsin. Biomacromolecules 9: 2170-2179.

48. Palomo JM, Fernández-Lorente G, Mateo C, Fuentes M, Guisan JM, et al. (2002) Enzymatic production of (3S,4R)-(-)-4-(4'-fluorophenyl)-6-oxopiperidin-3- carboxylic acid using a commercial preparation from Candida antarctica A: the role of a contaminant esterase. Tetrahedron: Asymmetry 13 2653-2659.

49. Mendes AA, Giordano RC, Giordano RLC, de Castro HF (2011) Immobilization and stabilization of microbial lipases by multipoint covalent attachment on aldehyde-resin affinity: Application of the biocatalysts in biodiesel synthesis. $J$ Mol Catal B: Enzym 68: 109-115. 
Citation: Obregón WD, Cisneros JS, Ceccacci F Quiroga E (2015) A Highly Stable Biocatalyst Obtained from Covalent Immobilization of a NonCommercial Cysteine Phytoprotease. J Bioprocess Biotech 5: 211 doi: 10.4172/2155-9821.1000211

50. Klibanov AM (2001) Improving enzymes by using them in organic solvents. Nature 409: 241-246.

51. Yoon JH, Mckenzie D (2005) A comparison of the activities of three $\beta$-galactosidases in aqueous-organic solvent mixtures. Enzyme Microb Technol 36: 439-446.

52. Quiroga E, Priolo N, Marchese J, Barberis S (2006) Behaviour of araujiain, a cystein phytoprotease, in organic media with low water content. Electron $\mathrm{J}$ Biotechnol 9: 18-25.
53. Quiroga E, Camí G, Marchese J, Barberis S (2007) Organic solvents effect on the secondary structure of araujiain hl, in different media. Biochem Eng J 35 198-202.

54. Bordusa F1 (2002) Proteases in organic synthesis. Chem Rev 102: 4817-4868.

55. Nuijens T, Cusan C, Schepers ACHM, Kruijtzer JAW, Rijkers DTS, et al. (2011) Enzymatic synthesis of activated esters and their subsequent use in enzymebased peptide synthesis. J Mol Catal B: Enzym 71: 79-84.
Citation: Obregón WD, Cisneros JS, Ceccacci F Quiroga E (2015) A Highly Stable Biocatalyst Obtained from Covalent Immobilization of a Non-Commercial Cysteine Phytoprotease. J Bioprocess Biotech 5: 211 doi: 10.4172/21559821.1000211
Submit your next manuscript and get advantages of OMICS Group submissions

Unique features:

User friendly/feasible website-transt

- Digital articles to share and explor

Special features:

400 Open Access Journal

30,000 editorial team

21 days rapid review process

Quality and quick editorial, review and publication processing

Indexing at PubMed (partial), Scopus, EBSCO, Index Copernicus and Google Scholar etc

Sharing Option: Social Networking Enabled

Authors, Reviewers and Editors rewarded with online Scientific Credits

Better discount for your subsequent articles

Submit your manuscript at: www.omicsonline.org/submission 